\title{
STRATEGIES TO REVITALISE AGRO-FOOD VALUE CHAINS IN MEDIUM SIZED CITIES: THE CASE OF VILANOVA I LA GELTRÚ
}

\author{
David Fernández;; Lourdes Reig; Martin Alba; Zein Kallas; Lydia Lanzarote
}

\author{
*Centre for Agro-Food Economics and Deveopment (CREDA, Castelldefels, \\ david.fernandez.guerrero@upc.edu)
}

\section{Abstract}

In recent years, large and medium-sized cities around Spain and other European countries have developed strategies to contribute to the recovery of local agro-food value chains. Through approaches that pursue bottom-up participation and the empowerment of local agro-food stakeholders, these strategies aim to preserve and develop local food production and consumption. The present study intends to contribute to the existing literature, through a case study in the municipality of Vilanova i la Geltrú (Catalonia). Two aspects add to the study's distinctiveness: Firstly, it shows the potential of a specific workshop methodology, the World Café, to promote new idea generation and contribute to the bottom-up formulation of the agro-food strategy. Secondly, the municipality is a coastal, medium-sized city where rapid urbanisation has put pressure on the continuity of agro-food activities.

Keywords: Agro-food strategies, World Café workshops, medium-sized cities, urbanisation

\section{Introduction and aims}

Recently, large and medium-sized cities in Spain and other European countries have turned to local strategies to promote the recovery of agro-food value chains. Indeed, global voluntary agreements like the Milan Urban Food Policy Pact have propelled the emergence of these strategies, to the point that a recent review (Magarini \& Porreca, 2019) identified 101 initiatives related to such strategies in Europe. These strategies share similar goals such as supporting the development of agro-food initiatives in urban and periurban spaces; stimulating the development of short food chains; facilitating population's access to local healthy food; or developing governance mechanisms for the agro-food system.

Participatory approaches to policy development have been put in place with workshops providing room for societal stakeholders' involvement in the definition of policy goals. As indicated in a recent review (De Cunto et al., 2017) reliance on bottom-up participation is a trait that differentiates modern, local agro-food strategies from previous, state-led strategies. An example of these innovations is the establishment of food policy councils (Bonomelli \& Eggen, 2017).

The present study aims to contribute to the literature on local agro-food strategies, by exploring the participatory dynamics generated by World Café workshops in strategy design. World Cafés aim to facilitate the creative inclusion of ideas, avoiding premature consensus formation (Fouché \& Light, 2011; Steier et al., 2015). By reshuffling participants across working groups, World Cafés promote new idea generation. Concretely, this workshop methodology does so because it reduces the risk that one or few participants dominate the conversation, provides more opportunities for less participative participants to voice their views, and generates a creative environment. Furthermore, the latter development is incentivised by the layout of the World Café; they are set in spaces resembling a café setting, with snacks and beverages.

Additionally, this study intends to contribute to the literature by showing how local agro-food strategies can be developed in a medium-sized coastal city, despite urbanisation. Vilanova i la Geltrú, in Spain (hereafter Vilanova) is a municipality with a long-standing relationship with the primary sector, which is still visible in its fishing port and its horticulture. However, rapid urbanisation has led to a decrease in the economic relevance of its agro-food sector.

Thus, the study intends to answer the following research question and sub-question:

- How can the World Café workshop methodology contribute to stakeholders' involvement and empowerment, in the design of local agro-food strategies?

- How can World Cafés contribute to the aforementioned goal, in medium-sized municipalities facing intense urbanisation pressure?

\section{Methodology}

The World Café workshops were organised as part of a research project carried out by the authors, supporting the local government in the design of an agro-food strategy for the municipality. Two workshops were organised in the Polytechnic University of Catalonia (UPC) in Vilanova, in the last two weeks of April. The first workshop focused on agriculture (not including farming); the second on fisheries, 
aquaculture and farming. Both of them lasted approximately 90 minutes, and counted with participants of the value chain:

- $\quad$ Agriculture: 7 participants, including 2 producers, 1 retailer (supermarket), 2 retailers (market), 1 restaurant, 1 consumer organisation.

- Fisheries, aquaculture and farming: 10 participants, including 1 producer, 2 retailers (supermarket), 3 retailers (market), 2 retailers (small shop), 2 restaurants.

Each workshop was supported by previous desk research and in-depth interviews with key stakeholders, and was organised in two stages. The first stage, inspired by the work of Ariño and Fernández (2021) and Vesnic-Alujevic et al. (2019) focused on future scenarios. Through SWOT analysis, opportunities and threats for the local agro-food value chain were explored, taking into account its current strengths and weaknesses. In the second stage, participants co-created action proposals exploiting the opportunities identified in the SWOT, while minimising threats. The actions identified during the workshop have been classified according to categories related to the agro-food value chain: i) Production, ii) Commercialisation, iii) Education and tourism; iv) governance.

Each stage was divided into two rounds so that participants would rotate as follows:

- First stage: Rotation between table A -strengths and weaknesses- and table B -opportunities and threats-.

- Second stage: Rotation between table A -actions related to production and commercialisationand table B -actions on education and tourism, and governance-

In the two weeks after the workshops, participants have prioritised, through and an online vote, proposals of action for each of the categories covered in the second stage. For each category, a ranking of three actions has been generated.

\section{Results}

\subsection{Context}

Located in the southern fringe of the metropolitan region of Barcelona, Vilanova has witnessed an intense increase in the size of its population in the last decades. This increase has been further exacerbated by the economic opportunities generated by tourism. Between 1998 and 2020, its population has grown by 35\%from 50.244 to 67.733 inhabitants-, compared to $23 \%$ in the province of Barcelona.

In parallel, the role of the primary sector has become negligible. Within agriculture and farming (Table 1) there has been a decrease in the number of heads of establishment, and a rapid ageing of them.

Table 1. Heads of agricultural and farming establishments, distributed by age

\begin{tabular}{|lllllll|}
\hline Year & Total & $\begin{array}{l}\text { Until 34 years } \\
\text { old }\end{array}$ & $\begin{array}{l}\text { 35 to 44 years } \\
\text { old }\end{array}$ & $\begin{array}{l}\text { 45 to 54 years } \\
\text { old }\end{array}$ & $\begin{array}{l}\text { 55 to 64 years } \\
\text { old }\end{array}$ & $\begin{array}{l}\text { 65 years old or } \\
\text { more }\end{array}$ \\
\hline $1999-2009$ & $-5,48 \%$ & $-33,33 \%$ & $-33,33 \%$ & $0,00 \%$ & $-33,33 \%$ & $78,57 \%$ \\
\hline 2009 & 69 & 4 & 8 & 14 & 18 & 25 \\
\hline 1999 & 73 & 6 & 12 & 14 & 27 & 14 \\
\hline \multicolumn{7}{c}{ Source: Idescat (Agrarian Census) } \\
\hline
\end{tabular}

Similarly, Vilanova has witnessed a 15\% decrease in the size of its fishing fleet between 2012 and 2020. Compared to a $28 \%$ decrease in the province of Barcelona, the fall in Vilanova might appear less steep. However, Vilanova has a long-standing tradition as a fishing port, and its fishing catch has a strong reputation among the local population as well as in the Barcelona metropolitan region (see below).

\subsection{World Café workshops}

During the SWOT analysis, a current scenario emerged, characterised by weaknesses such as the youth's low degree of interest in direct buying to producers, consumers' lack of knowledge on local and seasonal products, and the lack of certification systems guaranteeing products' traceability. Despite these limitations, strengths could be identified in the existence of a network of establishments selling local products and a consumer segment interested in local produce.

In fact, participants identified an opportunity in the growth of consumer segments interested in local, ecological and seasonal products. Another opportunity emerged from the possibility to tap into the good reputation enjoyed by Vilanova among consumers in the Barcelona metropolitan area. Well managed - 
amply diffused and with a certification system guaranteeing products' traceability-, a "produced in Vilanova" certification was also seen as an opportunity. Other opportunities emerged from the municipal government's interest in helping the sector and understanding its needs. However, threats were identified in increasing supermarket competition and the lack of systems to certify effectively products' origin.

Narrowing down to the primary sector branches, crucial weaknesses in agriculture concerned the difficult access of young farmers to the land and the bad shape of infrastructures. This weakness was reflected in threats such as the risk that owners transform their properties to non-agricultural purposes. Among fishermen, the existence of a well prepared port was seen as a strength. Fishermen, however, saw themselves threatened by the lack of trust around fish consumption, due to contamination from microplastics and other pollutants. Another threat emerged from consumers' interest in convenience products. These views contrasted with those of the representative from aquaculture production, who saw opportunities for aquaculture in fishermen's knowledge base, and in the proximity to Barcelona's consumer base and distribution infrastructure.

As for the second stage (Table 2), participants in the two workshops supported actions aimed at:

- Reinforcing consumers' capacity to distinguish local products compared to non-local products, as well as their interest in local products. Concretely, the proposals include awareness raising campaigns $-1 \mathrm{C}$ agriculture; $1 \mathrm{~B}$ farming, fishing and aquaculture- as well as educational activities in public schools on seasonal products $-2 \mathrm{C}$ agriculture; $1 \mathrm{C}$ farming, fishing and aquaculture--

- Tighter cooperation between the municipality and the primary sector, both in promotional activities $-1 \mathrm{D}$ and 2D farming, fishing and aquaculture- and in public procurement programmes for municipal food services $-1 \mathrm{~B}$ agriculture-.

- Reinforcing short commercialisation channels, such as the local market in the maritime district 2B agriculture-, and the links between local markets and restaurants $-2 \mathrm{~B}$ farming, fisheries and aquaculture-.

\begin{tabular}{|c|c|c|c|c|}
\hline \multicolumn{5}{|c|}{ Table 2. Results of the workshops } \\
\hline & & 1st activity & 2nd activity & 3rd activity \\
\hline \multirow{4}{*}{ 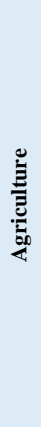 } & A) Production & $\begin{array}{c}\text { 1A: Protect existing rural areas against } \\
\text { urban growth }\end{array}$ & $\begin{array}{l}\text { 2A: Facilitate land transfer from retired } \\
\text { to young farmers }\end{array}$ & 3A: Improve irrigation infraestructures \\
\hline & \multirow{2}{*}{$\begin{array}{l}\text { B) Comercialisation } \\
\text { C) Education and } \\
\text { tourism }\end{array}$} & $\begin{array}{l}\text { 1B: Municipal public procurement for } \\
\text { food services (school restaurants, } \\
\text { catering) relying on local, seasonal } \\
\text { food }\end{array}$ & $\begin{array}{l}\text { 2B: Support the local market in the } \\
\text { maritime district }\end{array}$ & $\begin{array}{l}\text { 3B: Support small trade, outside the } \\
\text { local markets }\end{array}$ \\
\hline & & $\begin{array}{l}\text { 1C: Develop awareness raising } \\
\text { campaigns on farming topics }\end{array}$ & $\begin{array}{l}\text { 2C: Carry out educational activities on } \\
\text { public schools about seasonal products }\end{array}$ & $\begin{array}{l}\text { 3C: Diffuse the historical heritage of } \\
\text { the local water reservoir }\end{array}$ \\
\hline & D) Governance & $\begin{array}{l}\text { 1D: Implement the Catalan law on } \\
\text { agrarian spaces to ensure young } \\
\text { farmers' land access }\end{array}$ & $\begin{array}{l}\text { 2D: Mediate between landowners and } \\
\text { young farmers to facilitate access to } \\
\text { land }\end{array}$ & $\begin{array}{c}\text { 3D: Tighter municipality involvement } \\
\text { in events organised by producers, such } \\
\text { as fairs }\end{array}$ \\
\hline \multirow{5}{*}{ 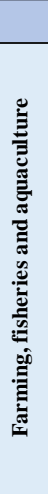 } & & 1st activity & 2nd activity & 3rd activity \\
\hline & A) Production & $\begin{array}{l}\text { 1A: Ensure control and verification of } \\
\text { fisheries traceability, to ensure good } \\
\text { use of the Vilanova "brand" }\end{array}$ & $\begin{array}{l}\text { 2A: Promote short commercialisation } \\
\text { channels incentivising cooperation } \\
\text { between producers and distributers }\end{array}$ & $\begin{array}{c}\text { 3A: Support innovation initiatives at the } \\
\text { port of Vilanova, diversifying their } \\
\text { sources of income }\end{array}$ \\
\hline & B) Comercialisation & $\begin{array}{l}\text { 1B: Lead awareness raising campaigns } \\
\text { on seasonal fish consumption }\end{array}$ & $\begin{array}{l}\text { 2B: Improve communication between } \\
\text { local markets and restaurants through a } \\
\text { website or app }\end{array}$ & $\begin{array}{l}\text { 3B: Increase the attractiveness of the } \\
\text { market through new technologies }\end{array}$ \\
\hline & $\begin{array}{l}\text { C) Education and } \\
\text { tourism }\end{array}$ & $\begin{array}{l}\text { 1C: Lead awareness raising campaigns } \\
\text { on local products, in quantities suited } \\
\text { to prevent food waste }\end{array}$ & $\begin{array}{l}\text { 2C: Promote educational actions (.e.g. } \\
\text { courses) on local, seasonal products }\end{array}$ & $\begin{array}{l}\text { 3C: Focus educational actions on local, } \\
\text { seasonal products in families with } \\
\text { children }<12 \text { years old }\end{array}$ \\
\hline & D) Governance & $\begin{array}{l}\text { 1D: Tighter cooperation between } \\
\text { municipality and primary sector in } \\
\text { promotional actions }\end{array}$ & $\begin{array}{l}\text { 2D: Tighter involvement of primary } \\
\text { sector stakeholders in promotional } \\
\text { actions carried out by the municipality } \\
\text { and the county }\end{array}$ & $\begin{array}{l}\text { 3D: Create, related to a local trade } \\
\text { mark for Vilanova products, a fidelity } \\
\text { card for local products }\end{array}$ \\
\hline & & irce: & boration & \\
\hline
\end{tabular}

Beyond these common traits, different types of actions were emphasised in each workshop. Participants in the agriculture workshop prioritised actions directed to prevent urbanisation and facilitate young farmers' access to these lands $-1 \mathrm{~A}, 2 \mathrm{~A}, 1 \mathrm{D}, 2 \mathrm{D}$-. Among fisheries and farming representatives there was clear interest in strengthening the distinctive character of the Vilanova brand through traceability $-1 \mathrm{~A}-$ and incentives to local product consumption $-3 \mathrm{D}-$.

\section{Conclusions}


Developing an agro-food strategy in a densely urbanised municipality like Vilanova could be a complex endeavour. Nevertheless, participants in the workshops displayed considerable interest in contributing to the strategy, and the format of World Café workshops appeared to stir this interest. Departing from current strengths and weaknesses, they could rapidly identify future opportunities and threats during the SWOT analysis. In the second stage, these opportunities and threats served as a starting point for action proposals. Participants, in particular those less inclined to talk, were encouraged by table hosts to propose ideas, and a lively discussion ensued. Finally, through an online voting the creative energy generated during the workshops has been condensed into a narrow set of priorities, providing clear guidelines for the local agrofood strategy.

The characteristics of the World Café prompted an open conversation. A café-style setting diminished the relevance of local hierarchies, helping participants feel at ease. Additionally, the reshuffling of working groups across tables made it more difficult for dominant stakeholders to impose their views. Certainly, implementing the World Café methodology does not guarantee the bottom-up formulation of local agrofood strategies in urbanised municipalities; however the outcomes of the present study suggest its potential.

\section{References}

Ariño, X., \& Fernández, T. (2021). "Building responsible research and innovation ecosystems through shared agendas. The case of the B30 territory". Working Paper SeeRRI Project.

Bonomelli, V., \& Eggen, M. (2017). "Food policy councils: Towards democratic governance of food systems?". FIAN Belgium, analytical note.

De Cunto, A., Tegoni, C., Sonnino, R., \& Michel, C. (2017). Food in cities: study on innovation for a sustainable and healthy production, delivery, and consumption of food in cities. Eurocities report.

Fouché, C., \& Light, G. (2011). "An invitation to dialogue: "The world café" in social work". Qualitative Social Work, 10(1), 28-48.

Magarini, A., \& Porreca, E. (2019). "European cities leading in urban food systems transformation: connecting Milan \& FOOD 2030. Independent expert report”. Luxembourg: Publications Office of the European Union.

Steier, F., Brown, J., \& Da Silva, F. M. (2015). “The World Café in action research settings”. In Bradbury, H. (Eds.): The SAGE handbook of action research, vol. 3 (pp. 211-219).

Vesnic-Alujevic, L., Stoermer, E., Rudkin, J.-E., Scapolo, F., \& Kimbell, L. (2019). The Future of Government 2030+: A Citizen-Centric Perspective on New Government Models. EUR 29664 EN. Publications Office of the European Union.

\section{Acknowledgments}

Thanks are due to the municipality of Vilanova i la Geltrú for its support in the workshops. 